University of Nebraska - Lincoln

DigitalCommons@University of Nebraska - Lincoln

Foraging Habitat for Shorebirds in Southeastern Missouri and its Predicted Future Availability

Daniel J. Twedt

USGS Patuxent Wildlife Research Center, dtwedt@usgs.gov

Follow this and additional works at: https://digitalcommons.unl.edu/usgsstaffpub

Twedt, Daniel J., "Foraging Habitat for Shorebirds in Southeastern Missouri and its Predicted Future Availability" (2013). USGS Staff -- Published Research. 728.

https://digitalcommons.unl.edu/usgsstaffpub/728

This Article is brought to you for free and open access by the US Geological Survey at DigitalCommons@University of Nebraska - Lincoln. It has been accepted for inclusion in USGS Staff -- Published Research by an authorized administrator of DigitalCommons@University of Nebraska - Lincoln. 


\title{
Foraging Habitat for Shorebirds in Southeastern Missouri and its Predicted Future Availability
}

\author{
Daniel J. Twedt
}

Received: 1 August 2012 /Accepted: 11 April 2013 /Published online: 27 April 2013

(C) US Government 2013

This article is a U.S. government work, and is not subject to copyright in the United States.

\begin{abstract}
Water management to protect agriculture in alluvial floodplains often conflicts with wildlife use of seasonal floodwater. Such is the case along the Mississippi River in southeastern Missouri where migrating shorebirds forage in shallow-flooded fields. I estimated the current availability of habitat for foraging shorebirds within the New Madrid and St. Johns Basins based on daily river elevations (19432009), under assumptions that shorebirds forage in open habitat with water depth $<15 \mathrm{~cm}$ and use mudflats for 3 days after exposure. The area of shorebird foraging habitat, based on replicated 50-year random samples, averaged 975 ha per day during spring and 33 ha per day during fall. Adjustments to account for habitat quality associated with different water depths, duration of mudflat exposure, intraseasonal availability, and state of agricultural crops, indicated the equivalent of 494 ha daily of optimal habitat during spring and 11 ha during fall. Proposed levees and pumps to protect cropland would reduce shorebird foraging habitat by $80 \%$ : to 211 ha (108 optimal ha) per day during spring and 9 ha ( $<3$ optimal ha) per day during fall. Alternative water management that allows natural flooding below a prescribed elevation would retain nearly all existing shorebird foraging habitat during fall and about $60 \%$ of extant habitat during spring.
\end{abstract}

Keywords Digital elevation model · Flood control ·

Floodwater · Foraging, Habitat quality $\cdot$ Mudflat $\cdot$ Shorebird habitat $\cdot$ Temporal availability

Electronic supplementary material The online version of this article (doi:10.1007/s13157-013-0422-0) contains supplementary material, which is available to authorized users.

D. J. Twedt $(\square)$

United States Geological Survey, Patuxent Wildlife Research

Center, 2524 South Frontage Road,

Vicksburg, MS 39180, USA

e-mail: dtwedt@usgs.gov

\section{Introduction}

For centuries, mankind has recognized that the fertile soils of alluvial floodplains yield abundant crops. However, farming bottomlands is risky-as untimely flooding may destroy planted crops. Thus, prophylactic measures, such as levees, dams, and canals, have often been undertaken to protect alluvial farmland from flooding while crops are present. Conflicts arise when wildlife or other ecological processes are adversely impacted by these flood mitigation efforts. Recognizing that long-term environmental benefits result from alluvial flooding (Bayley 1995), flood control advocates are increasingly seeking compromises that provide socio-economic benefits for agriculture yet still retain some of the benefits afforded by a natural flood regime (Poff et al. 1997).

Along these lines, I sought to evaluate the impact on wildlife habitat of different water management scenarios associated with proposed flood control along the Mississippi River in southeastern Missouri, USA. I developed and applied a robust methodology to assess the current availability of shorebird foraging habitat associated with historical variation in river elevation. This same methodology was used to predict future availability of shorebird foraging habitat under different water management scenarios that could be employed after flood control measures are implemented. This affords planners an effective method to evaluate the tradeoffs between flood control for agriculture and the resultant availability and quality of wildlife habitat.

Extensive earthen levees that confine rivers within their battures (i.e., the alluvial land between low-water stage and the levees) and other flood control measures were implemented along the Mississippi River and its tributaries after record flooding in 1937 (Stevens et al. 1975). As a result levees are now present along most of lower Mississippi River (Nunnally et al. 1987). In addition, a 
network of canals throughout southeastern Missouri has facilitated drainage of wetlands for agriculture.

Hydrological change alters adjacent ecosystems (Gergel et al. 2002). As such, historically forested land within southeastern Missouri has largely been converted to agriculture, yet the St. Johns and New Madrid Basins remain subject to seasonal inundation (Fig. 1). In part, this flooding results from a gap in the levee system which permits backwater from the Mississippi River to enter the New Madrid Basin when water elevation is high. Historical data suggest that an average (2-year event) backwater flood in the New Madrid Basin inundates approximately 7,000 ha, of which 4,700 ha are used for agriculture (unpublished data, U.S. Army Corps of Engineers, http://www.mvm.usace.army. mil/stjohns/overview/default.asp). Even so, significant backwater flooding inundated over 20,000 ha in 1973 , and this basin served as a floodway for the Mississippi River when levees were breached in 1937 and 2011.

Conversely, contiguous levees protect the St. Johns Basin from backwater flooding, but gravity-outlet, box culverts through this levee allow drainage when the Mississippi River elevation is lower than the water elevation within the Basin interior. However, when culvet gates are closed, surface drainage accumulates and lands behind the protective levee are inundated. In the St. Johns Basin, an average 2-year flood events inundates approximately 4,000 ha, of which 2,500 ha are in agriculture (unpublished data, U.S. Army Corps of Engineers).
Because most of southeastern Missouri was historically forested, suitable habitat for shorebirds was uncommon. Yet with most of the land within the New Madrid and St. Johns Basins converted to agriculture, seasonal inundation now provides shallow water and mudflats suitable for foraging by shorebirds (Smith et al. 1996; Twedt and Loesch 1999). Shorebirds (Charadriiformes) comprise a diverse group of small to medium-large birds that generally forage for invertebrates in shallow water (Recher 1966; Brown et al. 2001) in areas of sparse vegetation, such as harvested agricultural lands (Helmers 1992; Rottenborn 1996; Twedt et al. 1998; Isola et al. 2000; Cole et al. 2002).

Few shorebird species breed in this region or are present during winter; however, killdeer (Charadrius vociferous) and common snipe (Gallinago gallinago) during winter, are exceptions. The greatest abundance and species diversity of shorebirds within this region occur during spring and fall, as en-route migrant shorebirds make "rest and refueling" stops during their northbound (spring) and southbound (fall) passages (Skagen 1997; Elliott and McKnight 2000; Skagen 2006). Based on conservation planning documents (Elliott and McKnight 2000; Loesch et al. 2000), and empirical observations reported to the Lower Mississippi Valley Joint Venture Shorebird Monitoring Program (http://www.lmvjv.org/shorebird/ default.asp), shorebirds of small or medium body size comprise the preponderance of these shorebirds (Table 1).

Although many factors contribute to habitat selection by shorebirds (Burger 1984; Jing et al. 2007), suitable water
Fig. 1 St. Johns and New Madrid Basin study area in southeastern Missouri. Forest, open water, and urban landcover (left) were deemed unsuitable for foraging shorebirds. Relative flood frequency (right) was based on multi-temporal analysis of satellite imagery (Ducks Unlimited, unpublished data)

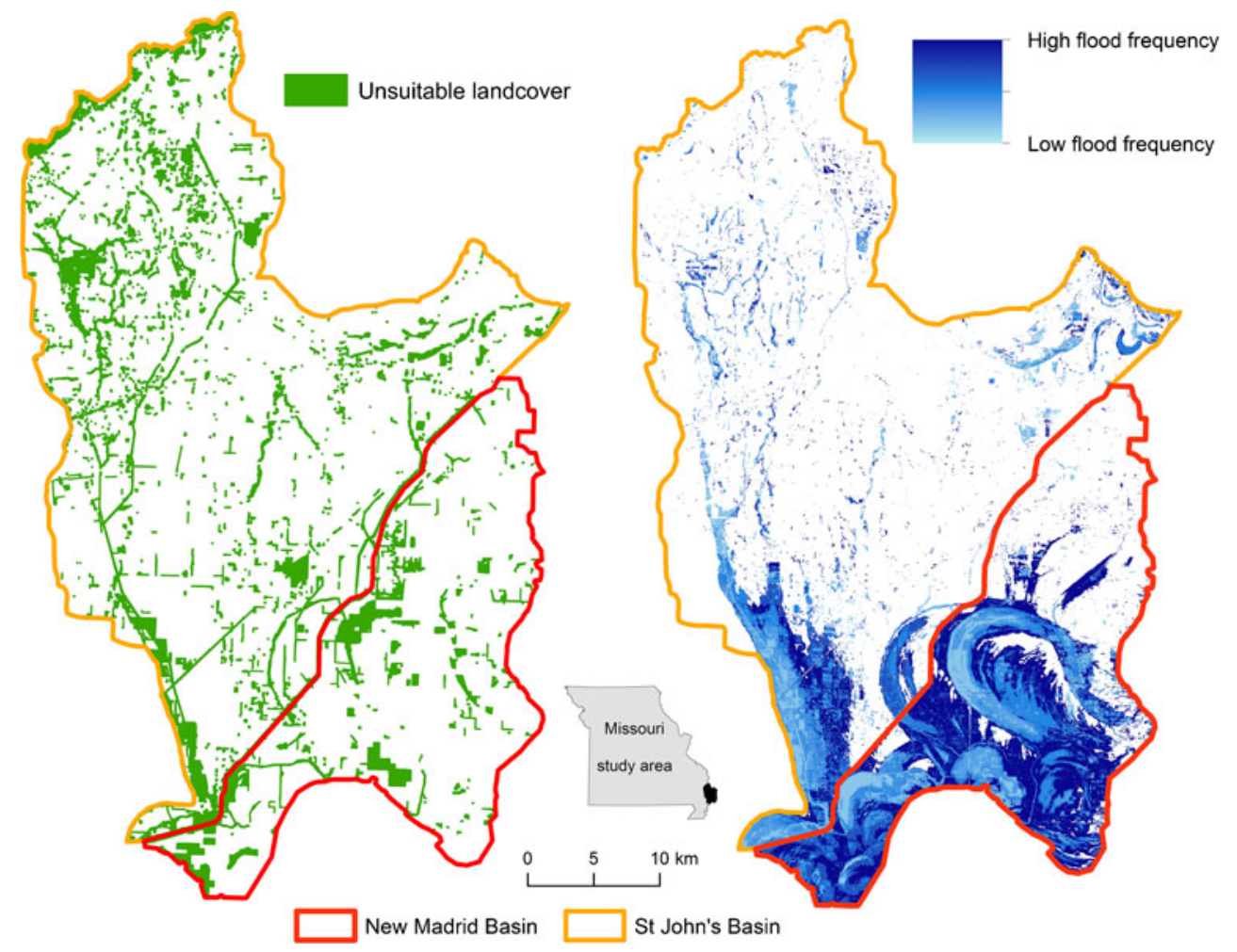


Table 1 Shorebird species, body size, presumed foraging depth $(\mathrm{cm})$, and number of shorebirds detected during fall on surveys in the 4 states (Missouri, Kentucky, Tennessee, and Arkansas) near the St. JohnsNew Madrid study area that were reported to the Lower Mississippi Valley Joint Venture (LMVJV) Shorebird Monitoring Program

${ }^{\text {a }} \mathrm{S}=$ body length $\leq 190 \mathrm{~mm}, \mathrm{M}=$ body length 191-350 $\mathrm{mm}$, and $\mathrm{L}=$ body length $>350 \mathrm{~mm}$ (Skagen and Knopf 1993)

${ }^{\mathrm{b}}$ LMVJV Shorebird Monitoring Program: http://www.lmvjv.org/ shorebird/default.asp

\begin{tabular}{|c|c|c|c|c|}
\hline Common name & Scientific name & Size $^{\mathrm{a}}$ & Depth & Number $^{\mathrm{b}}$ \\
\hline Spotted sandpiper & Actitis macularia & M & $<4$ & 535 \\
\hline Ruddy turnstone & Arenaria interpres & M & $<6$ & 10 \\
\hline Upland sandpiper & Bartramia longicauda & M & $<6$ & 19 \\
\hline Sanderling & Calidris alba & M & $<3$ & 257 \\
\hline Dunlin & Calidris alpina & M & $<6$ & 152 \\
\hline Baird's sandpiper & Calidris bairdii & $\mathrm{S}$ & $<6$ & 925 \\
\hline Red knot & Calidris canutus & M & $<6$ & 2 \\
\hline White-rumped sandpiper & Calidris fuscicollis & $\mathrm{S}$ & $<6$ & 540 \\
\hline Stilt sandpiper & Calidris himantopus & M & $<9$ & 8785 \\
\hline Western sandpiper & Calidris mauri & $\mathrm{S}$ & $<6$ & 2521 \\
\hline Pectoral sandpiper & Calidris melanotos & M & $<6$ & 42549 \\
\hline Least sandpiper & Calidris minutilla & $\mathrm{S}$ & $<6$ & 46626 \\
\hline Semipalmated sandpiper & Calidris pusilla & $\mathrm{S}$ & $<6$ & 11817 \\
\hline Calidris spp. (peeps) & Calidris spp. & $\mathrm{S}$ & $<6$ & 4674 \\
\hline Willet & Catoptrophorus semipalmatus & $\mathrm{L}$ & $<12$ & 19 \\
\hline Piping plover & Charadrius melodus & $\mathrm{S}$ & $<3$ & 25 \\
\hline Semipalmated plover & Charadrius semipalmatus & $\mathrm{S}$ & $<3$ & 1672 \\
\hline Killdeer & Charadrius vociferus & M & $<3$ & 15292 \\
\hline Common snipe & Gallinago gallinago & M & $<6$ & 92 \\
\hline Black-necked stilt & Himantopus himantopus & $\mathrm{L}$ & $<20$ & 4082 \\
\hline Short-billed dowitcher & Limnodromus griseus & M & $<12$ & 1097 \\
\hline Long-billed dowitcher & Limnodromus scolopaceus & M & $<12$ & 4622 \\
\hline Dowitcher spp. & Limnodromus spp. & M & $<12$ & 1377 \\
\hline Marbled godwit & Limosa fedoa & $\mathrm{L}$ & $<12$ & 18 \\
\hline Red-necked phalarope & Phalaropus lobatus & M & various & 18 \\
\hline Wilson's phalarope & Phalaropus tricolor & M & various & 598 \\
\hline American golden-plover & Pluvialis dominica & M & $<9$ & 80 \\
\hline Black-bellied plover & Pluvialis squatarola & M & $<9$ & 518 \\
\hline American avocet & Recurvirostra americana & $\mathrm{L}$ & $<12$ & 793 \\
\hline Greater yellowlegs & Tringa melanoleuca & M & $<12$ & 787 \\
\hline Solitary sandpiper & Tringa solitaria & M & $<6$ & 267 \\
\hline Lesser yellowlegs & Tringa flavipes & M & $<12$ & 6533 \\
\hline Buff-breasted sandpiper & Tryngites subruficollis & M & $<3$ & 371 \\
\hline
\end{tabular}

depth is an important determinant of foraging habitat selection (Safran et al. 1997). More than $70 \%$ of shorebird species forage in water depths $<10 \mathrm{~cm}$ and many species are restricted to water depths of $<5 \mathrm{~cm}$ (Helmers 1992; Dinsmore et al. 1999; Skagen et al. 1999). Most small and medium size shorebirds forage in water depths $<6 \mathrm{~cm}$ with some shorebirds foraging in exposed mudflat habitats or in water of depth from 6 to $15 \mathrm{~cm}$ (Table 1). Shallow water depth was the most important predictor of shorebird abundance within the Rainwater Basin in Nebraska (Webb et al. 2010).

Shorebirds forage on a variety of substrates, from bare ground to $>75 \%$ vegetative cover, but most species preferentially use sites with sparse $(<25 \%)$ vegetative cover (Davis and Smith 1998; Dinsmore et al. 1999). In Texas, $95 \%$ of foraging flocks used sites with $<33 \%$ vegetation
(Davis 1996). Moreover, abundance of some shorebird species is negatively correlated with vegetation height (Colwell and Dodd 1995) with most species found on sites where vegetation height is less than half of their body height.

On wetlands that are managed for shorebird foraging habitat, water is often retained for weeks or months to stimulate production of aquatic invertebrates (Helmers 1992). Yet natural wetlands and rivers harbor myriad aquatic invertebrates upon which shorebirds forage (Smith et al. 2012). In addition, terrestrial insects and other invertebrates found in cultivated fields provide food for shorebirds when these fields are flooded (Evans-Ogden et al. 2008). Thus, lands subjected to backwater flooding that have sparse or short vegetation (e.g., agricultural fields or grazed grasslands) provide foraging sites for migrating shorebirds. 
Given current land use within southeastern Missouri, supplying the necessary mix of water depth and vegetative structure during the time that corresponds with shorebird migration is the most important issue for shorebird conservation in this region (Brown et al. 2001).

The U.S. Army Corps of Engineers (USACE) has proposed completion of an earthen levee to protect the New Madrid Basin and installation of water pumping facilities within both the St. Johns and New Madrid Basins. Proposed pumps would transport water that accumulates behind closed water control gates over the protective levees with deposition in the Mississippi River batture. The combination of levee and pumps is expected to eliminate backwater flooding and reduce headwater flooding within these basins, thereby diminishing the area of habitat suitable for foraging shorebirds. Because its connection with the Mississippi River will be severed, habitat loss is anticipated to be greater within the New Madrid Basin.

To assess the effect of completed levees and operation of pumps, I sought to quantify the area of shorebird habitat within the St. Johns and New Madrid Basins based on historical flood conditions, and to predict the area of shorebird habitat available under presumed future flood conditions. Specifically, my objectives were to:

1. Develop a methodology to quantify the area of potential shorebird foraging habitat (i.e., land cover and hydrologic condition deemed suitable for shorebirds) relative to intra-basin hydrological elevations (National Geodetic Vertical Datum: NGVD) that were derived from Mississippi River elevations (a.k.a., river stages), historical precipitation, topography, and land cover,

2. Estimate the area of shorebird habitat within the St. Johns and New Madrid Basins that is associated with each $3.048 \mathrm{~cm}(0.1 \mathrm{ft})$ increment of intra-basin water elevation,

3. Quantify the availability of shorebird habitat within the St. Johns and New Madrid Basins during periods of northward and southward migration of shorebirds, based on historical intra-basin water elevations, and

4. Predict future availability of shorebird habitat during periods of northward and southward migration of shorebirds within the St. Johns and New Madrid Basins based on projected future intra-basin water elevations.

\section{Methods}

Study Area

Area of investigation included 126,325 ha in the St. Johns Basin and 47,670 ha in the New Madrid Basin of southeastern
Missouri (Fig. 1). Greater than $90 \%(163,235$ ha) of landcover in these basins is cropland, pasture, or other sparse vegetation, that if shallowly inundated provide habitat conditions suitable for foraging shorebirds (Fig. 1). I considered areas with tall or dense landcover (e.g., forest or shrubs) unsuitable for shorebirds. Similarly, areas in permanent water (i.e., lakes and ponds) were assumed to be predominately of depths that exceed shorebird foraging limits and thus not suitable shorebird habitat (Fig. 1).

Initial landcover classifications within the St. Johns and New Madrid Basins were obtained at 30-m resolution from the Multi-Resolution Land Characterization Consortium's 2001 National Land Cover data (available online at: http:// www.mrlc.gov/nlcd01_data.php, Homer et al. 2004, 2007). Land use was verified by conducting site visits on $20 \%$ of the project area and crop types were assigned to agricultural lands (K. Pigott, U.S. Army Corps of Engineers, personal communication).

I reclassified the above landcover raster into binary descriptors of shorebird habitat (suitable vs. non-suitable) where non-suitable habitat included all forest classes (including wooded wetlands), shrubland, open water, and highdensity developed areas (i.e., cities). All other cover classes, including all crops, fallow fields, orchards, grassland, pasture, low- and medium-density developed lands (i.e., farmsteads and suburban areas), and herbaceous or emergent wetlands, were considered potentially suitable as shorebird habitat.

Land cover data were updated using 2007 aerial imagery obtained from the U.S. Department of Agriculture, National Agricultural Imagery Program (http://www.fsa.usda.gov/ $\mathrm{FSA} /$ apfoapp area $=$ home $\&$ subject $=$ prog $\&$ topic $=$ nai). Individual land-use polygons were visually compared with aerial imagery and, where inconsistencies were identified, corrections were made to the land-use data to conform to aerial imagery. However, this comparison of landcover raster data with 2007 aerial photography revealed marked discrepancies in areas deemed suitable shorebird foraging habitat. That is, some areas of forest cover were classified as 'open' habitats whereas other areas of 'open' habitat were classified as forested. Therefore, I converted the binary depiction of shorebird habitat to a vector format and subsequently employed 'heads-up' digitization to correct habitat polygons to reflect habitats interpreted from 2007 aerial photography. Only areas within the St. Johns and New Madrid Basins that had landcover suitable for shorebirds during 2007 were considered when estimating areas of potential shorebird foraging habitat (Table 2).

\section{Wetland Reserve Program}

Some areas deemed potentially suitable for shorebirds were known to be enrolled in the U.S. Department of Agriculture's Wetland Reserve Program (WRP). As most WRP enrollments 
Table 2 Area (ha) of land cover class (circa 2007, U.S. Army Corps of Engineers) and respective crop type class and shorebird habitat class within the St. Johns and New Madrid Basins in Missouri

\begin{tabular}{lllll}
\hline Land cover & Crop type & Shorebird habitat & New Madrid & St. Johns \\
\hline Forest and shrubland & Non-crop & Unsuitable & 534 & 2,483 \\
Developed: high intensity & & 2 & 179 \\
Open water & & 492 & 380 \\
Woody wetland & Corn-sorghum & Suitable & 3,596 & 5,389 \\
Corn & & 5,229 & 23,799 \\
Sorghum & Cotton & 1,158 & 583 \\
Cotton & Fallow & 123 & 2,641 \\
Developed: $\leq$ medium intensity & & 2699 & 11,160 \\
Fallow & Grass-herbaceous & 78 & 292 \\
Herbaceous & & 89 & 124 \\
Pasture/hay/grass & & 157 & 3,539 \\
Wetlands & Soybean & 123 & 120 \\
Soybean & Wheat & 24,820 & 32,863 \\
Winter wheat & Rice & 7,346 & 28,516 \\
Rice & Other crops & 257 & 1,440 \\
Other small grains & & 18 & 279 \\
Other crops & & 2 & 69 \\
\hline
\end{tabular}

within this region are reforested or converted to semipermanent water, these areas will likely harbor little shorebird habitat in the future. Thus, all lands enrolled in WRP were removed from consideration as shorebird habitat.

In addition, U.S. Department of Agriculture personnel, in cooperation with USACE personnel, estimated that WRP enrollment over the next 50 years will increase by 345 ha in the New Madrid Floodway and by 1,200 ha within the St. Johns Basin. Based on the area of existing WRP enrollments (i.e., average contract size: 87 ha in St. Johns, 67 ha in New Madrid), enrollment of as few as 2 contracts per year would realize these WRP projections within 10 years. Therefore I assumed $10 \%$ of projected future enrollment in WRP occurred each year for 10 years and thereafter was stable. Elevations of projected WRP enrollments were assumed comparable to elevations within existing WRP enrollment. Therefore proportionally equivalent areas were annually (for 10 years) removed from potential shorebird habitat. If an elevation had insufficient area for allotted removal, proportional removal was increased among remaining elevations until requisite area was attained.

\section{Foraging Habitat}

Because most shorebirds forage in wet habitats, I assumed only areas that were inundated or recently exposed from inundation (i.e., mudflats) were suitable for use by foraging shorebirds. However, based on predominant habitat use by small and medium-sized shorebirds, I assumed habitats that were shallowly flooded with $\leq 6.1 \mathrm{~cm}$ of water provided optimal foraging conditions (Davis 1996; Safran et al.
1997; Isola et al. 2000). These shallowly flooded areas were assigned maximum habitat suitability $(s=1.0)$. Compared to habitats flooded with $\leq 4 \mathrm{~cm}$ of water, $63 \%$ fewer foraging flocks used habitats flooded at depths from 4 to $16 \mathrm{~cm}$ (Davis 1996). Therefore, I assumed these more deeply flood habitats had less than optimal suitability which was inversely related to water depth but retained suitability $\geq 60 \%$ of maximum. Thus, I assigned suitability scores to flood depths: $6.1-9.15 \mathrm{~cm}(s=0.8), 9.15-12.2 \mathrm{~cm}(s=0.7)$, and $12.2-15.25 \mathrm{~cm}(s=0.6)$.

Mudflats were used by foraging shorebird flocks at a frequency $41 \%$ of that observed in presumed optimal shallow-water flooded habitat (Davis 1996). Because of relatively less use of mudflats by foraging shorebirds, as well as the presumed spatial heterogeneity in mudflat habitat conditions, and uncertainty regarding the temporal stability of exposed mudflats due to variation in drainage and rates of evapo-transpiration, I assumed mudflats were less suitable for shorebird foraging than shallow-water flooded habitat. I inversely weighted suitability of mudflats relative to length of exposure after inundation with the least suitable mudflat habitat retaining $40 \%$ of maximum suitability. Thus, mudflat exposed 1 day had suitability $60 \%$ that of maximum $(s=0.6)$, exposed 2 days $(s=0.5)$, and exposed 3 days $(s=0.4)$.

\section{Migration Chronology}

The quantitative distributions of shorebirds within the 93 day (15 March-15 June) spring migration period or within the 122 day ( 1 July-30 October) fall migration period 
are not uniform: Fewer birds are present at the beginning and end of each migration period. Because site-specific data on temporal distribution of shorebirds were not available, I presumed the temporal distribution of small and medium shorebirds was as provided by Skagen et al. (1999) between $35^{\circ}$ and $40^{\circ}$ north latitude in North America. I modeled abundance as a function of time (day) within each migration period. The best-fit regression models of shorebird abundance were:

Spring $=1.012($ day $)+0.0255\left(\right.$ day $\left.^{2}\right)-0.0004\left(\right.$ day $\left.^{3}\right)$; Fall $=4.2538($ day $)-0.0598\left(\right.$ day $\left.^{2}\right)+0.0002\left(\right.$ day $\left.^{3}\right)$,

where day was the interval after the first day within each migration period. From these regression models I estimated the intervals within each migration period wherein $50 \%$ and $90 \%$ of the migrating shorebird populations were predicted to be within the study area. Assuming the greatest benefit occurs when the greatest abundance of shorebirds have access to suitable foraging habitat, I assigned maximum value $(t=1.0)$ to those days (24 April-23 May during spring and 5 August-16 September during fall) wherein $50 \%$ of the population was predicted to be present. For those remaining days of each migration period that harbored an additional $40 \%$ of the population, thereby accounting for $90 \%$ of total population (3 April-8 June during spring and 14 July-13 October during fall), migration period value was reduced to $90 \%$ of maximum $(t=0.9)$. For all other days within the spring and fall migration periods, during which only $10 \%$ of the shorebird population was predicted to be present, I reduced migration period value to $50 \%$ of maximum $(t=0.5)$. Using these migration period values, the daily area of shorebird foraging habitat equivalence, previously estimated from suitability of flood conditions in areas of suitable landcover, was modified to reflect temporal availability of habitat within each migration period.

\section{Crop Chronology}

Suitability of inundated lands as shorebird habitat likely diminishes with increased density and height of vegetation. As such, I ascertained the usual first and last planting and harvest dates for crops grown in Missouri (National Agricultural Statistics Service 2010) and using 9 reclassified land cover types (Table 2) developed stepfunctions of suitability for each of 7 crop types that reflected: decreased suitability of habitat after planting (crop suitability; $c=0.75$ ), an additional decrease in suitability upon presumed maturation $(c=0.5)$, increased suitability upon initiation of harvest $(c=0.75)$, and subsequent return to maximum suitability $(c=1.0)$ upon completion of harvest (Fig. 2). Land cover classified as fallow or developed (open, low density, or medium density) was assumed to be maintained in suitable condition as shorebird habitat and retained maximum suitability $(c=1.0)$, whereas land cover classes deemed unsuitable as shorebird habitat were assumed to have zero crop suitability $(c=0.0)$.

I calculated the area of each crop type class within each $3.05 \mathrm{~cm}$ contour elevation for each river basin and determined its proportion of all potentially suitable shorebird habitats within the respective contour elevation. For each day of the year, I summed the products of proportion of crop type class (constant among days) and crop suitability index (varied among days) to determine an elevation-day crop development index. Where the elevation-day crop development index was the proportion of crop type class times the crop type class suitability index for the day, summed over 8 crop type classes (Table 2). To account for intra-annual change in crop status within each contour elevation, I decreased the area of optimally suitable shorebird habitat using its corresponding elevation-day crop development index. Thus for each day, the optimal-equivalent area of shorebird foraging habitat was calculated as:

Area $=\sum\left(\right.$ ha $\left.* \mathrm{~S}_{*} \mathrm{t} * \mathrm{CDI}\right)$, summed over all elevations,

where

ha area in hectares inundated $<16 \mathrm{~cm}$ or exposed from inundation within the previous 3 days

$\mathrm{s} \quad$ water depth or mud exposure suitability

$\mathrm{t}$ temporal suitability within spring or fall migration periods.

CDI elevation-day crop development index.

\section{Water Elevations}

Neither St. Johns nor New Madrid Basin had river gauge (water elevation) records suitable for direct estimation of intra-basin water levels. Therefore U.S. Army Corps of Engineers personnel derived daily intra-basin water elevations for each of these basins from 1943 to 2009 based on: 1) period of record data from New Madrid river gauge (MS115, -89.53222, 36.58306, $0.2 \mathrm{~km}$ downstream from the mouth of St. Johns Bayou at river navigation mile 889.0, http://www.mvm.usace.army.mil/ hydraulics/docs/gagtitl/ms115hdr.htm); 2) regional precipitation records from weather stations at New Madrid and Sikeston, Missouri and Cairo, Illinois; 3) topography; and 4) land cover. From these data, daily intra-basin water elevations were calculated for the St. Johns Basin 

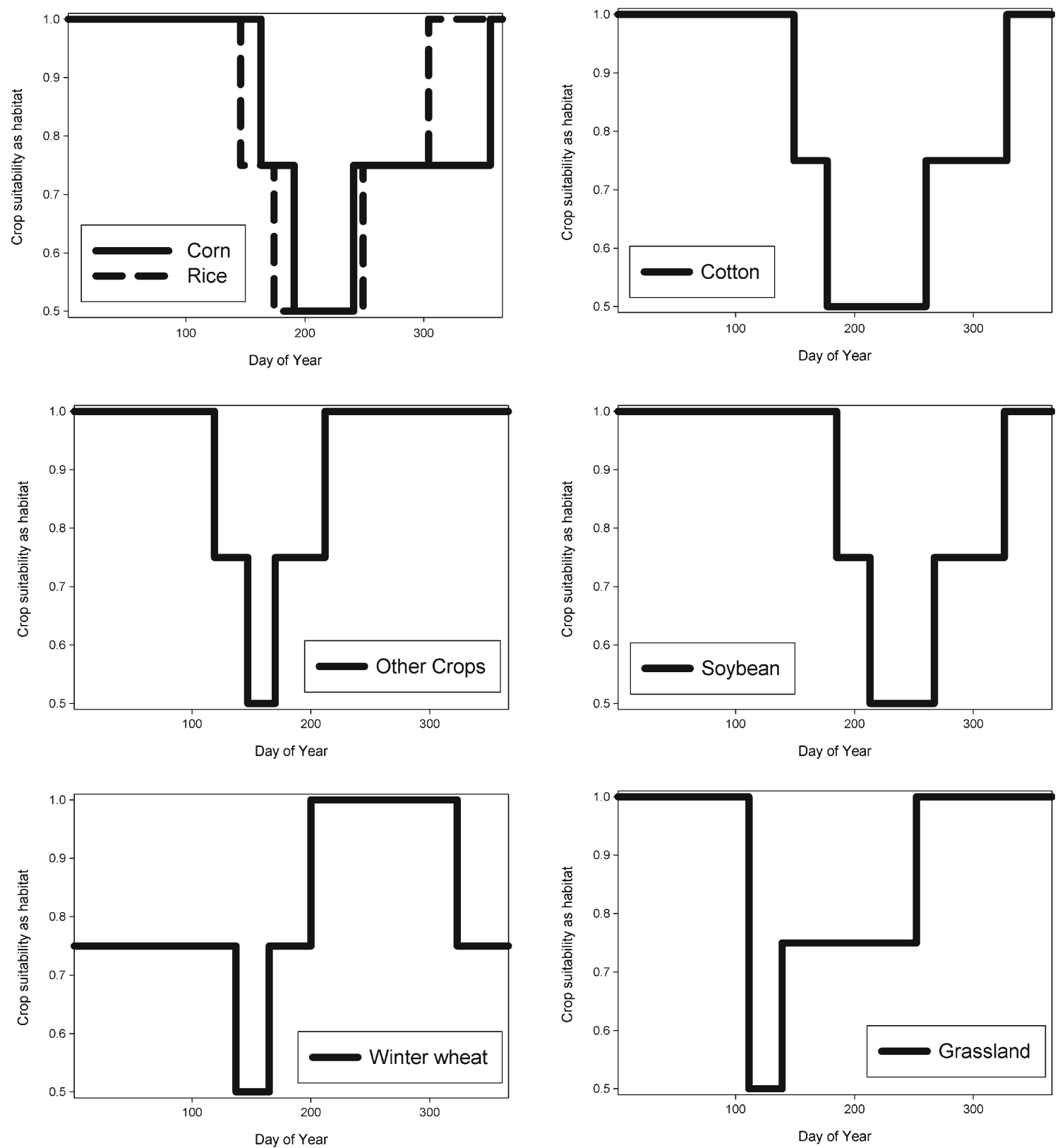

Fig. 2 Step functions used to characterize crop-type suitability for every day of year based on first and last planting and harvesting dates within Missouri and a presumed 4 week period of rapid initial growth (National Agricultural Statistics Service 2010)

(Online Resource A1) and the New Madrid Basin (Online Resource B1) using the computer program HUXRAIN (B. J. Bruchman, Memphis District, U.S. Army Corps of Engineers, personal communication).

\section{Flood Assessment}

I obtained digital vertical elevation (NGVD) contours at $0.3048 \mathrm{~m}(1 \mathrm{ft})$, derived from light detection and ranging (LiDAR) data within the New Madrid Basin and derived from geodetic and hydrologic data within the St. Johns Basin, from U.S. Army Corps of Engineers
(K. R. Pigott, Memphis District, U.S. Army Corps of Engineers). A fundamental underlying assumption for subsequent estimation of shorebird habitat within the St. Johns and New Madrid Basins was that these $0.3048 \mathrm{~m}$ elevation contours reasonably approximated the extent of floodwater associated with their respective intra-basin water elevations.

I used ArcMap 9.3 (ESRI, Redlands, California) geographic information system to spatially interpolate $3.05 \mathrm{~cm}(0.1 \mathrm{ft})$ interval elevations between each pair of elevation contours (Online Resource C1). The total area (ha) included in each $3.05 \mathrm{~cm}$ elevation was 
summed separately within each basin and represented the area inundated at each corresponding intra-basin water elevation.

\section{Model Application}

Within each river basin, for each day from 1 January 1943 to 30 November 2009, I projected intra-basin water elevations for each water elevation interval and estimated the area of landcover suitable for shorebird foraging that was inundated with $\leq 15.25 \mathrm{~cm}$ of water. Concurrently, I projected inundations associated with water elevations for each of the previous 3 days. When inundation was greater during any of the previous 3 days (i.e., falling water levels), the area of suitable landcover exposed after inundation was estimated separately for each of these 3 days. That is, the area between the daily water-land interface contour ( 0 depth) and the contour representing the previous day's flood extent was summed to represent mudflat habitat exposed on each day. The total daily area of potential shorebird habitat with suitable land cover within the St. Johns and New Madrid Basins was the combined areas of inundation $\leq 15.25 \mathrm{~cm}$ in depth and mudflats exposed within the previous 3 days. For each day, this sum represented the total area (i.e., footprint) available to shorebirds for foraging.

Not all of the area available to shorebirds is optimal for foraging and areas of presumed suitable shorebird foraging habitat within each flood-depth interval were weighted by their depth-specific suitability. Similarly, areas of exposed mudflats were weighted relative to suitability associated with length of exposure after prior inundation. All suitable habitats were also temporally weighted to account for the likelihood of migrating shorebirds being present in the study area, and to account for seasonal change in development of crops. Daily sums of appropriately weighted foraging areas, which account for presumed foraging quality and temporal suitability, provided a measure of 'optimal' habitat equivalence (i.e., the equivalent area of suitable shorebird foraging habitat if quality and temporal availability were optimal).

To determine the area of shorebird foraging habitat available during spring and during fall, I estimated the mean and variance associated with 200 bootstrap samples, wherein each sample consisted of 50 years of intra-basin water elevation data that were randomly selected (with replacement) from historical records for years 1943-2009. I assessed the range of annual variation in available shorebird foraging habitat by identifying annual minimum and maximum areas of shorebird foraging habitat during spring and during fall. For each daily water-level scenario within the spring and fall migration periods (1943-2009) for the St. Johns Basin (Online Resource A1) and New Madrid Basin (Online Resource B1), I estimated: (1) the total area of potential shorebird foraging habitat (i.e., open land) that was flooded regardless of depth, (2) total area of potential shorebird foraging habitat that was inundated with $\leq 15.25 \mathrm{~cm}$ or exposed from inundation for $\leq 3$ days, (3) the equivalent area of shorebird foraging habitat after accounting for presumed quality of foraging habitat, (4) the equivalent area of shorebird foraging habitat that also accounted for temporal availability of habitat within migration periods, and (5) the optimally equivalent area of foraging habitat that accounted for habitat quality, and temporal availability, as well as crop planting, growth, and harvest.

\section{Forecast Prediction}

As congressionally authorized, proposed flood control measures will ostensibly restrict floodwater elevations from spring through fall to $\leq 85.04 \mathrm{~m}$ NGVD within the St. Johns Basin and $\leq 84.73 \mathrm{~m}$ NGVD within the New Madrid Basin. Pumping of impounded water would commence within each basin at these prescribed elevations and continue until sump elevations were reduced to $84.43 \mathrm{~m}$ NGVD in the St. Johns Basin and $83.82 \mathrm{~m}$ NGVD in the New Madrid Basin.

Recognizing that extreme rainfall events and pump limitations will likely prevent strict adherence to authorized flood elevation limits, and that intentional retention of sump elevation above falling river elevation is possible, U.S. Army Corps of Engineers personnel (B. Bruchman, personal communication) generated projected estimates of water elevations under authorized flood restrictions for the St. Johns Basin (Online Resource A2) and the New Madrid Basin (Online Resource B2) using methodologies identified above to derive daily water elevations that reflect historical water elevations. I forecast the probable area of foraging habitat for shorebirds based on intra-basin water elevations using the same methods described above, but with historical daily water elevations replaced with daily water elevations projected under authorized flood restrictions.

Because flood events that do not impact crop production or imperil residential areas are socio-politically acceptable and environmentally beneficial, three alternative water management scenarios that allow greater inundation were also evaluated within the New Madrid Basin (Table 3). The most liberal of these proposed alternatives would provide flood protection to elevations $\geq 88.39 \mathrm{~m}$ NGVD throughout the year whereas more conservative watermanagement alternatives provide increased flood protection from spring through fall (Table 3). Using the methodologies described above, daily estimates of intrabasin water elevation were projected to reflect the impact of alternative water management (Online Resource B3, B4, and B5). These projections were subsequently used to predict the daily area of shorebird foraging 
Table 3 Water elevations (m NGVD) associated with requisite management actions for three alternative (Alt. 1, Alt. 2, and Alt. 3) water management scenarios proposed for the New Madrid Basin upon completion of contiguous Mississippi River levee and installation of

\begin{tabular}{|c|c|c|c|c|c|c|c|c|c|}
\hline \multirow[t]{2}{*}{ Dates } & \multicolumn{3}{|c|}{ Close gate } & \multicolumn{3}{|c|}{ Start pump } & \multicolumn{3}{|c|}{ Stop pump } \\
\hline & Alt. 1 & Alt. 2 & Alt. 3 & Alt.1 & Alt. 2 & Alt. 3 & Alt.1 & Alt. 2 & Alt. 3 \\
\hline 15 November-28 February & 87.63 & 87.63 & 87.63 & 88.24 & 88.24 & 88.24 & 87.78 & 87.78 & 87.78 \\
\hline 1 March-15 April & 87.17 & 86.56 & 87.63 & 87.78 & 87.17 & 88.24 & 87.48 & 86.87 & 87.78 \\
\hline 16 April-30 May & 86.56 & 85.95 & 87.63 & 86.56 & 85.95 & 88.24 & 85.95 & 85.34 & 87.78 \\
\hline 1 June-14 November & 84.89 & 84.89 & 87.63 & 85.19 & 85.19 & 88.24 & 84.89 & 84.89 & 87.78 \\
\hline
\end{tabular}

pumps. Congressionally authorized intra-basin water elevations are $84.73 \mathrm{~m}$ before starting to pump water from inside levees with continued pumping until water elevation of $83.82 \mathrm{~m}$ is achieved habitat that would be available under proposed alternative water management scenarios.

\section{Results}

Based on historical river elevations, shorebird foraging habitat is available on $>80 \%$ of days during spring but $<50 \%$ of days during fall and is present on more days within the St. Johns Basin than within the New Madrid Basin (Table 4). Despite a smaller area, average daily shorebird foraging habitat within the New Madrid Basin was markedly greater than that available within the St. Johns Basin (Table 5). Mean daily area of shorebird foraging habitat within both basins was 29 times greater during spring (974.9 \pm 126.4 ha; $\mathrm{x} \pm \mathrm{SD}$ ) than during fall (33.4 $\pm 13.5 \mathrm{ha}$; Table 5).

After adjusting for habitat quality, temporal availability, and crop condition, mean daily optimally equivalent area of shorebird foraging habitat within both basins was $>40$ times more abundant during spring (494.3 \pm 66.9 ha) than during fall (11.0 \pm 5.0 ; Table 6). During an average spring day, shorebird foraging habitat was present on nearly 1,000 ha of 3,700 flooded ha, but habitat quality and temporal availability suggest $<500$ ha of optimally equivalent habitat were available for foraging. In contrast, during an average fall day only 33 ha of shorebird foraging habitat were present, with the equivalence of $<12$ ha of optimal foraging habitat.

Upon completion of levee, adherence to pump maintained sump elevation $\leq 85.04 \mathrm{~m}$ NGVD within the St. Johns Basin

Table 4 Number of days per year shorebird foraging habitat was available during the 93-day spring migration period and the 122-day fall migration period within the St. Johns and New Madrid Basins in southeastern Missouri, 1943 to $2009(n=67)$

\begin{tabular}{llllll}
\hline Basin & Migration & Mean & SE & Minimum & Maximum \\
\hline New Madrid & Spring & 77.6 & 2.1 & 20 & 93 \\
& Fall & 23.5 & 2.7 & 0 & 122 \\
\multirow{2}{*}{ St. Johns } & Spring & 90.4 & 0.8 & 51 & 93 \\
& Fall & 60.7 & 3.6 & 4 & 122 \\
\hline
\end{tabular}

would reduce the total availability of shorebird foraging habitat within this basin by about $30 \%$ in spring and approximately $40 \%$ in fall (Table 5). In contrast, maintaining the sump elevation at $\leq 84.73 \mathrm{~m} \mathrm{NGVD}$, as authorized within the New Madrid Basin, would reduce the total availability of shorebird foraging habitat within this basin by $\geq 98 \%$ during both spring and fall (Table 5) with the optimal equivalent area of shorebird foraging habitat similarly reduced during both migration periods (Table 6).

An alternative water management scenario that affords year-round flood protection only for elevations $\geq 88.39 \mathrm{~m}$ NGVD within the New Madrid Basin (Alt. 3: Table 3) will preserve current shorebird foraging habitat during fall and retain nearly $>50 \%$ of current shorebird foraging habitat during spring (Table 6). Moreover this alternative water management scenario should encompasses $>50 \%$ of annual variation in shorebird foraging habitat associated with historical river elevations (Table 6). In contrast, alternative water management scenarios proposed for the New Madrid Basin which allow increased inundation only during spring (Alt.1 and 2: Table 3) do not mitigate loss of shorebird foraging habitat during fall, and during spring would likely result in $70 \%-85 \%$ reduction in shorebird foraging habitat (Table 5) and optimally equivalent shorebird foraging habitat (Table 6).

\section{Discussion}

Because reduction in the area of shorebird foraging habitat associated with completion of levees was greater within the New Madrid Basin, alternative water management scenarios were proposed to mitigate loss of shorebird foraging habitat within this basin. All alternative water management scenarios increased the area of available shorebird foraging habitat during spring compared to that provided under authorized conditions. However, compared to current habitat availability within the New Madrid Basin (based on historical water levels), even the most liberal alternative water management scenario reduced potential foraging habitat in spring by 
Table 5 Daily area (ha) of shorebird habitat, irrespective of quality, during spring (15 March-15 June) and fall (1 July-30 October) within the St. Johns and New Madrid Basins in southeastern Missouri. All projections based on 2007 landcover and 200 bootstrap samples of daily river elevations, each of comprised of 50 years, randomly selected from 1943 to 2009. Current conditions based on historical river elevations, whereas authorized (and alternative) conditions reflect restricted water elevations due to completion of levees and operation of pumps

\begin{tabular}{|c|c|c|c|c|c|c|c|c|c|c|}
\hline \multirow[t]{2}{*}{ Basin } & \multirow[t]{2}{*}{ Migration } & \multirow[t]{2}{*}{ Conditions } & \multicolumn{6}{|c|}{50 year projections } & \multicolumn{2}{|c|}{ Annual variation } \\
\hline & & & Mean & SD & $95 \% \mathrm{lcl}$ & $95 \%$ ucl & Min & Max & Low & High \\
\hline \multirow[t]{4}{*}{ St. Johns } & \multirow[t]{2}{*}{ Fall } & Current & 13.0 & 3.0 & 7.1 & 18.9 & 5.0 & 23.6 & 0.0 & 158.0 \\
\hline & & Authorized & 8.0 & 2.1 & 3.9 & 12.1 & 3.5 & 15.3 & 0.0 & 91.9 \\
\hline & \multirow[t]{2}{*}{ Spring } & Current & 284.7 & 40.2 & 205.9 & 363.5 & 184.9 & 401.6 & 0.9 & 1242.4 \\
\hline & & Authorized & 200.4 & 29.5 & 142.7 & 258.1 & 113.9 & 275.8 & 0.4 & 775.1 \\
\hline \multirow[t]{10}{*}{ New Madrid } & \multirow[t]{5}{*}{ Fall } & Current & 20.4 & 10.5 & 0.0 & 41.4 & 0.7 & 63.1 & 0.0 & 532.0 \\
\hline & & Authorized & 0.5 & 0.1 & 0.3 & 0.7 & 0.2 & 0.8 & 0.0 & 7.1 \\
\hline & & Alternative 1 & 0.7 & 0.2 & 0.3 & 1.0 & 0.2 & 1.2 & 0.0 & 15.9 \\
\hline & & Alternative 2 & 0.7 & 0.2 & 0.3 & 1.0 & 0.3 & 1.2 & 0.0 & 15.9 \\
\hline & & Alternative 3 & 19.9 & 9.3 & 1.6 & 38.2 & 1.7 & 48.5 & 0.0 & 471.7 \\
\hline & \multirow[t]{5}{*}{ Spring } & Current & 690.2 & 86.2 & 521.2 & 859.2 & 483.9 & 1053.8 & 0.0 & 2082.7 \\
\hline & & Authorized & 11.1 & 5.4 & 0.4 & 21.8 & 3.6 & 30.5 & 0.0 & 285.4 \\
\hline & & Alternative 1 & 201.2 & 24.6 & 153.0 & 249.4 & 140.4 & 287.6 & 0.0 & 601.9 \\
\hline & & Alternative 2 & 104.1 & 10.7 & 83.2 & 125.0 & 76.5 & 136.3 & 0.0 & 428.3 \\
\hline & & Alternative 3 & 389.4 & 40.1 & 310.8 & 468.0 & 256.0 & 510.6 & 0.0 & 928.0 \\
\hline
\end{tabular}

$44 \%$, whereas the more conservative water management scenarios resulted in habitat reduction of $>71 \%$ (Table 5). Moreover, proposed water management scenarios that prevent flooding during fall nearly eliminate shorebird foraging habitat, with projected average daily

Table 6 Daily area (ha) of 'optimally equivalent' shorebird habitat, relative to foraging conditions and presumed shorebird abundance, during spring (15 March-15 June) and fall (1 July-30 October) within the St. Johns and New Madrid Basins in southeastern Missouri. All projections based on 2007 landcover and 200 bootstrap samples of shorebird habitat $<1$ ha during fall. Conversely, allowing water levels to fluctuate year-round below $88.39 \mathrm{~m}$ NGVD likely would result in retention of an area of foraging habitat for shorebirds during fall comparable to that which currently exists in the New Madrid Basin.

daily river elevations, each comprised of 50 years, randomly selected from 1943 to 2009. Current conditions based on historical river elevations, whereas authorized (and alternative) conditions reflect restricted water elevations due to completion of levees and operation of pumps

\begin{tabular}{|c|c|c|c|c|c|c|c|c|c|c|}
\hline \multirow[t]{2}{*}{ Basin } & \multirow[t]{2}{*}{ Migration } & \multirow[t]{2}{*}{ Conditions } & \multicolumn{6}{|c|}{50 year projections } & \multicolumn{2}{|c|}{ Annual variation } \\
\hline & & & Mean & $\mathrm{SD}$ & $95 \% \mathrm{lcl}$ & $95 \%$ ucl & Min & Max & Low & High \\
\hline \multirow[t]{4}{*}{ St. Johns } & \multirow[t]{2}{*}{ Fall } & Current & 4.0 & 1.1 & 1.9 & 6.1 & 1.4 & 7.7 & 0.0 & 59.6 \\
\hline & & Authorized & 2.5 & 0.7 & 1.2 & 3.9 & 1.0 & 4.8 & 0.0 & 32.5 \\
\hline & \multirow[t]{2}{*}{ Spring } & Current & 149.8 & 22.5 & 105.7 & 193.9 & 96.9 & 217.1 & 0.5 & 741.6 \\
\hline & & Authorized & 103.3 & 16.1 & 71.8 & 134.8 & 56.5 & 147.0 & 0.2 & 441.1 \\
\hline \multirow[t]{10}{*}{ New Madrid } & \multirow[t]{5}{*}{ Fall } & Current & 7.0 & 3.9 & 0.0 & 14.7 & 0.2 & 23.8 & 0.0 & 205.2 \\
\hline & & Authorized & 0.2 & 0.0 & 0.1 & 0.2 & 0.1 & 0.4 & 0.0 & 2.6 \\
\hline & & Alternative 1 & 0.2 & 0.1 & 0.1 & 0.4 & 0.1 & 0.4 & 0.0 & 6.3 \\
\hline & & Alternative 2 & 0.2 & 0.1 & 0.1 & 0.4 & 0.1 & 0.4 & 0.0 & 6.3 \\
\hline & & Alternative 3 & 7.0 & 3.6 & 0.0 & 14.1 & 0.6 & 17.6 & 0.0 & 194.3 \\
\hline & \multirow[t]{5}{*}{ Spring } & Current & 344.5 & 44.4 & 257.4 & 431.4 & 237.7 & 517.7 & 0.0 & 1098.4 \\
\hline & & Authorized & 4.9 & 2.1 & 0.9 & 8.9 & 1.7 & 11.8 & 0.0 & 98.5 \\
\hline & & Alternative 1 & 101.8 & 12.9 & 76.5 & 127.1 & 68.8 & 142.3 & 0.0 & 339.2 \\
\hline & & Alternative 2 & 49.3 & 5.1 & 39.3 & 59.2 & 35.4 & 63.9 & 0.0 & 164.5 \\
\hline & & Alternative 3 & 218.4 & 23.6 & 172.1 & 264.7 & 141.2 & 285.4 & 0.0 & 560.1 \\
\hline
\end{tabular}


I assumed intra-basin water elevations would fluctuate with river stage. However, the development of management pools and intentional retention of water would increase the area of shorebird foraging habitat above that identified by the model. Thus, water management prescribed specifically to create and maintain foraging habitat for shorebirds within either of these basins should increase the availability of foraging habitat without flooding beyond proposed management scenarios.

I assumed that $0.3048 \mathrm{~m}$ elevation contours developed by U.S. Army Corps of Engineers' personnel provided a reasonable approximation of the ground elevation and drainages within the St. Johns and New Madrid Basins. As such, the extent of floodwater associated with each respective intra-basin water elevation was accurately depicted through conformity to these elevation contours. Interpolated $3.048 \mathrm{~cm}$ elevation contours between adjacent $0.3048 \mathrm{~m}$ elevation contours were undoubtedly inexact. However, this shorebird foraging habitat model assumes that variation in flooded area is unbiased within the entirety of the landscape under consideration and thus, on average provides a reasonable approximation of suitably flooded areas. That is, the exact geographic distribution of areas assumed to be suitable for shorebird foraging was not accurately identified but the total area of suitably inundated and recently exposed (mudflat) habitat was presumed to be an accurate representation of daily conditions.

During the past 15 years, $>2,300$ ha of agricultural land have been enrolled in the Wetland Reserve Program with $>1,500$ additional ha anticipated to be enrolled within the St. Johns and New Madrid Basins. I assumed these additional enrollments would occur within the next 10 years and that the elevation distribution of future enrollment will be similar to past enrollment. When the geo-spatial extents of future WRP enrollments become known, removal of the associated land area will improve the prediction of potential shorebird habitat.

I assumed that past water levels provide a good prediction of future water levels. However, if future flood events are on average more frequent and of greater intensity as some climate models predict (Burkett et al. 2001), completion of levees and operation of pumps would markedly reduce intra-basin water levels and shorebird foraging habitat. Yet, because the area and duration of availability of shorebird foraging habitat would likely increase in association with more frequent and intense flood events, the extent and availability of shorebird foraging habitat may remain sufficient to support migrating shorebird populations. Conversely, if future flood events become less frequent and of lower intensity (i.e., lower water elevations or shorter duration), the effects of proposed levee and pumps would be lessened. Even so, a small reduction in a diminished shorebird foraging area may be detrimental to migrating shorebird populations.

Although the findings and projections of shorebird foraging habitat area developed within this study are limited to the two study area river basins within southeastern Missouri, the methodology and application used during this assessment are transferable to any river basin with extant historical records of river elevation and for which a suitable topographic depiction of elevation within the basin under consideration is available or can be developed. Thus, this technique may be applied by regional conservation planners to estimate the area of shorebird foraging habitat. Moreover, conservation planners could use resultant projection of the area of shorebird foraging habitat to guide, mitigate, and improve projected future habitat conditions based on different water management scenarios. Such comparisons allow assessment of the economic and ecological tradeoffs of different water management strategies and may provide insight regarding the need and justification for increased flood control measures.

Acknowledgments I thank A. S. Keister and J. M. Tirpak, Lower Mississippi Valley Joint Venture, U.S. Fish and Wildlife Service for assistance with development of methods and geographic implementation. Funding for this assessment was provided by Memphis District, U.S. Army Corps of Engineers with project specific elevation data and hydrological projections provided by K. R. Piggot, J. M. Koontz, and B. J. Bruchman. Reviews by A. B. Elliot, S. K. McKnight, R. M. Erwin, and E. B. Webb improved the study design and a joint review by R. Stiehl, C. Davis, S. Dinsmore, and S. Wdowinski improved this model and manuscript. Reference to commercial products or tradenames does not imply U.S. Government endorsement.

\section{References}

Bayley PB (1995) Understanding large river-floodplain ecosystems. Bioscience 45:153-158

Brown S, Hickey C, Harrington B, Gill R (eds) (2001) United States shorebird conservation plan, 2nd edn. Manomet Center for Conservation Sciences, Manomet

Burger J (1984) Abiotic factors affecting migrant shorebirds. In: Burger J, Olla BL (eds) Shorebirds: migration and foraging behavior. Plenum Press, New York, pp 1-72

Burkett V, Ritschard R, McNulty S, O'Brien JJ, Abt R, Jones J, Hatch U, Murray B, Jagtap S, Cruise J (2001) Potential consequences of climate variability and change for the southeastern United States. In: Climate Change Impacts in the United States: Potential Consequences of Climate Change and Variability and Change. Foundation Document. U.S. Global Change Research Program, Washington, DC and Cambridge University Press, Cambridge, UK, pp. 137-164, online at: http://globalchange.gov/publications/reports/scientificassessments/first-national-assessment

Cole ML, Leslie DM, Fisher WL (2002) Habitat use by shorebirds at a stopover site in the southern Great Plains. Southwest Nat 47:372-378 
Colwell MA, Dodd SL (1995) Waterbird communities and habitat relationships in coastal pastures of Northern California. Conserv Biol 9:827-834

Davis CA (1996) Ecology of spring and fall migrant shorebirds in the playa lakes region of Texas. Dissertation, Texas Tech University, Lubbock, $224 \mathrm{pp}$

Davis CA, Smith LM (1998) Ecology and management of migrant shorebirds in the playa lakes region of Texas. Wildl Monogr 140:1-45

Dinsmore SJ, Skagen SK, Helmers DL (1999) Shorebirds: an overview for the Prairie Pothole Joint Venture. Prairie Pothole Joint Venture, Denver, Colorado, 24 p. http://www.fort.usgs.gov/ Products/Publications/504/504.pdf. Accessed 28 July 2012

Elliott L, McKnight K (2000) U.S. Shorebird Conservation Plan: lower Mississippi Valley/Western Gulf Coastal Plain. Mississippi Alluvial Valley/West Gulf Coastal Plain Working Group, Lower Mississippi Valley Joint Venture. 29 pp. http://www.lmvjv.org/ library/USSP LMVWGCP.doc. Accessed 28 July 2012

Evans-Ogden LJ, Bittman S, Lank DB (2008) A review of agricultural land use by shorebirds with special reference to habitat conservation in the Fraser River Delta, British Columbia. Can J Plant Sci 88:71-83

Gergel SE, Dixon MD, Turner MG (2002) Consequences of humanaltered floods: levees, floods, and floodplain forests along the Wisconsin River. Ecol Appl 12:1755-1770

Helmers DL (1992) Shorebird management manual. Hemisphere Shorebird Reserve Network, Manomet

Homer C, Huang C, Yang L, Wylie B, Coan M (2004) Development of a 2001 National Land Cover Database for the United States. Photogramm Eng Remote Sens 70:829-840

Homer C, Dewitz J, Fry J, Coan M, Hossain N, Larson C, Herold N, McKerrow A, VanDriel JN, Wickham J (2007) Completion of the 2001 National Land Cover Database for the Conterminous United States. Photogramm Eng Remote Sens 73:337-341

Isola CR, Colwell MA, Taft OW, Safran RJ (2000) Interspecific differences in habitat use of shorebirds and waterfowl foraging in managed wetlands of California's San Joaquin Valley. Waterbirds 23:196-203

Jing K, Ma Z, Li B, Li J, Chen J (2007) Foraging strategies involved in habitat use of shorebirds at the intertidal area of Chongming Dongtan, China. Ecol Res 22:559-570

Loesch CR, Twedt DJ, Tripp K, Hunter WC, Woodrey MS (2000) Development of management objectives for waterfowl and shorebirds in the Mississippi Alluvial Valley. In: Bonney R, Pashley D, Cooper R, Niles L (eds) Strategies for bird conservation: the partners in flight planning process. Proceedings of the 3rd Partners in Flight workshop; 1995 October 1-5; Cape May, NJ. Proceedings RMRSP-16, Ogden, UT; United States Department of Agriculture, Forest Service, Rocky Mountain Research Station, pp 8-11
National Agricultural Statistics Service (2010) Usual Planting and Harvesting Dates of U.S. Field Crops. Agricultural Handbook 628. http://usda01.library.cornell.edu/usda/current/planting/planting-1029-2010.pdf Accessed 19 November 2012

Nunnally NR, Shield FD Jr, Hynson J (1987) Environmental considerations for levees and floodwalls. Environ Manag 11:183-191

Poff NL, Allan JD, Bain MB, Karr JR, Prestegaard KL, Richter BD, Sparks RE, Stromberg JC (1997) The natural flow regime: a paradigm for river conservation and restoration. BioScience 47:769-784

Recher HF (1966) Some aspects of the ecology of migrant shorebirds. Ecology 47:393-407

Rottenborn SC (1996) The use of coastal agricultural fields in Virginia as foraging habitat by shorebirds. Wilson Bull 108:783-796

Safran RJ, Isola CR, Colwell MA, Williams OE (1997) Benthic invertebrates at foraging locations of nine waterbird species in managed wetlands of the northern San Joaquin valley, California. Wetlands 17:407-415

Skagen SK (1997) Stopover ecology of transitory populations: the case of migrant shorebirds. Ecol Stud 125:244-269

Skagen SK (2006) Migration stopovers and the conservation of Arcticbreeding Calidridine sandpipers. Auk 123:313-322

Skagen SK, Knopf KL (1993) Toward conservation of midcontinental shorebird migrations. Conserv Biol 7:533-541

Skagen SK, Sharpe PB, Waltermire RG, Dillon MB (1999) Biogeographical profiles of shorebird migration in midcontinental North America. U. S. Geological Survey Biological Science Report 2000-0003, Fort Collins, CO. 167 p. http://www.mesc. usgs.gov/Products/Publications/555/toc.html. Accessed 28 July 2012

Smith WP, Hamel PB, Ford RP (1996) Mississippi Alluvial Valley forest conversion: implications for eastern North American avifauna. In: Proceedings 1993 Annual Conference Southeastern Association of Fish and Wildlife Agencies 47:460-469

Smith RV, Stafford JD, Yetter AP, Horath MM, Hine CS, Hoover JP (2012) Foraging ecology of fall-migrating shorebirds in the Illinois River Valley. PLoS One 7(9):e45121. doi:10.1371/ journal.pone. 0045121

Stevens MA, Schumm SA, Simons DB (1975) Man-induced changes of middle Mississippi River. J Waterw Harb Coast Eng Div 101:119-133

Twedt DJ, Loesch CR (1999) Forest area and distribution in the Mississippi Alluvial Valley: implications for breeding bird conservation. J Biogeogr 26:1215-1224

Twedt DJ, Nelms CO, Rettig VE, Aycock SR (1998) Shorebird use of managed wetlands in the Mississippi Alluvial Valley. Am Midl Nat 140:140-152

Webb EB, Smith LM, Vrtiska MP, Lagrange TG (2010) Effects of local and landscape variables on wetland bird habitat use during migration through the Rainwater Basin. J Wildl Manag 74:109-119 


\section{Supplementary Material (8)}

\section{Supplement \#1}

Daily intra-basin water elevations (feet NGVD) for St. Johns Basin derived from river elevations at the New Madrid gauge (MS115; navigation mile 889.0) on the Mississippi River, regional precipitation, topography, and land cover under historical flood conditions and projected areas of potential shorebird foraging habitat associated with these intra-basin water elevations (XLS $3041 \mathrm{~kb}$ )

\section{Supplement \#2}

Daily intra-basin water elevations (feet NGVD) for St. Johns Basin derived from river elevations at the New Madrid gauge (MS115; navigation mile 889.0) on the Mississippi River, regional precipitation, topography, and land cover predicted under authorized flood reduction conditions upon completion of the St. Johns-New Madrid Project and projected areas of potential shorebird foraging habitat associated with these intra-basin water elevations. (XLS $3020 \mathrm{~kb}$ )

\section{Supplement \#3}

Daily intra-basin water elevations (feet NGVD) for New Madrid Basin derived from river elevations at the New Madrid gauge (MS115; navigation mile 889.0) on the Mississippi River, regional precipitation, topography, and land cover under historical flood conditions and projected areas of potential shorebird foraging habitat associated with these intra-basin water elevations. (XLS $2784 \mathrm{~kb}$ )

\section{Supplement \#4}

Daily intra-basin water elevations (feet NGVD) for New Madrid Basin derived from river elevations at the New Madrid gauge (MS115; navigation mile 889.0) on the Mississippi River, regional precipitation, topography, and land cover predicted under authorized flood reduction conditions upon completion of the St. Johns-New Madrid Project and projected areas of potential shorebird foraging habitat associated with these intra-basin water elevations. (XLS $2857 \mathrm{~kb}$ )

\section{Supplement \#5}

Daily intra-basin water elevations (feet NGVD) for New Madrid Basin derived from river elevations at the New Madrid gauge (MS115; navigation mile 889.0) on the Mississippi River, regional precipitation, topography, and land cover predicted upon completion of the St. Johns-New Madrid Project but with water elevations allowed to exceed authorized elevations (Alternative 1; Table 3) and projected areas of potential shorebird foraging habitat associated with these intra-basin water elevations. (XLS $2858 \mathrm{~kb}$ )

\section{Supplement \#6}


Daily intra-basin water elevations (feet NGVD) for New Madrid Basin derived from river elevations at the New Madrid gauge (MS115; navigation mile 889.0) on the Mississippi River, regional precipitation, topography, and land cover predicted upon completion of the St. Johns-New Madrid Project but with water elevations allowed to exceed authorized elevations (Alternative 2; Table 3) and projected areas of potential shorebird foraging habitat associated with these intra-basin water elevations. (XLS $2860 \mathrm{~kb}$ )

\section{Supplement \#7}

Daily intra-basin water elevations (feet NGVD) for New Madrid Basin derived from river elevations at the New Madrid gauge (MS115; navigation mile 889.0) on the Mississippi River, regional precipitation, topography, and land cover predicted upon completion of the St. Johns-New Madrid Project but with water elevations allowed to exceed authorized elevations (Alternative 3; Table 3) and projected areas of potential shorebird foraging habitat associated with these intra-basin water elevations. (XLS $2861 \mathrm{~kb}$ )

\section{Supplement \#8}

Geographic information system methodology used to determine basin-wide $3.05-\mathrm{cm}$ $(0.1 \mathrm{ft}$; decifoot) digital elevation models within the New Madrid and the St. Johns Basins in southeastern Missouri. (PDF $48 \mathrm{~kb}$ ) 